\title{
Utilizing Conceptual Indexing to Enhance the Effectiveness of Vector Space Model
}

\author{
Aya M. Al-Zoghby \\ Computer Science Department, Faculty of Computers \& Information, Mansoura University, Egypt \\ E-mail: elzoghby.aya@gmail.com \\ Ahmed Sharaf Eldin Ahmed \\ Information Systems Department, Faculty of Computers \& Information, Helwan University, Egypt \\ E-mail: profase2000@yahoo.com
}

Taher T. Hamza

Computer Science Department, Faculty of Computers \& Information Science, Mansoura University, Egypt

E-mail: taher_hamza@yahoo.com

\begin{abstract}
One of the main purposes of the semantic Web is to improve the retrieval performance of search systems. Unlike keyword based search systems, the semantic search systems aim to discover pages related to the query's concepts rather than merely collecting all pages instantiating its keywords. To that end, the concepts must be defined to be used as a semantic index instead of the traditional lexical one. In fact, The Arabic language is still far from being semantically searchable. Therefore, this paper proposed a model that exploits the Universal Word Net ontology for producing an Arabic Concepts-Space to be used as the index of Semantic Vector Space Model. The Vector Space Model is one of the most common information retrieval models due to its capability of expressing the documents' structure. However, like all keyword-based search systems, its sensitivity to the query's keywords reduces its retrieval effectiveness. The proposed model allows the VSM to represent Arabic documents by their topic, and thus classify them semantically. This, consequently, enhances the retrieval effectiveness of the search system.
\end{abstract}

Index Terms - Semantic Web; Semantic Concepts; UWN; Vector Space Model; Arabic Language

\section{Introduction}

Search engines are the most indispensable tools used in navigating the information published on the Web. However, having the Web as the biggest global unstructured database complicates its machine understandability and processability. This, in turn, makes the ability to accurately acquire the desired information extremely difficult. Moreover, the query words may sometimes be ambiguous since different people may use different terminologies for the same concept, Synonymous, while, on the other hand, they may use the same words for different concepts, Polysemous [1]-[2]. Thus, most of the search engines face the problem of capturing the true purport of the user's query. Therefore, the main task of the search engines is to accurately interpret the users' needs, handle the relevant knowledge from different information sources, and deliver the authentic and relevant results to each userindividually [3]-[4]-[5].

In terms of recall/precision, the traditional search engines can be described as: with high-recall, they have low precision. This is mainly caused due to the sensitivity of their results to the keywords, and the misinterpretation of the synonymous and Polysemous [6]. Therefore, even if all relevant pages are retrieved, some irrelevant documents are also retrieved, which is affecting the precision. On the other hand, if some of the relevant pages are missed, this leads to low recall. Therefore, the alternative is the Semantic Search Engines (SSEs) that use the Ontological concepts for indexing rather than the standard lexicons used in the traditional search engines. Thus, the semantic search engines aim to get pages referring to specific concepts, rather than collecting all pages that just mentioned the query's keywords; which may already be ambiguous [7]-[8]. This way, the problem of expressing the same semantic concept using different terminologies can be resolved since these terminolog ies will be recognizable via the Ontological representation of that concept. Moreover, the semantic search engines can utilize the Generalization / Specialization properties of Ontologies hierarchy. Therefore, if it fails to find any relevant documents, it may ind icate more general answers, and if too many answers are retrieved, the search engine may suggest some specializations [7]-[8]. This way, the returned results will be more relevant, and those missed will be retrieved, which means higher recall with more precision [9]. 
Unfortunately, however, the Arabic language is still not fully supported through SSEs [10]. Although Swoogle $^{1}$, Hakia ${ }^{2}$, SenseBot ${ }^{3}$, and Deep Dyve ${ }^{4}$ are among the top SSEs, they have low to no support of Arabic. As Arabic Web sites are increasing constantly, search systems that handle the semantics of Arabic Language come to be essential.

The Vector Space Model (VSM) is one of the most common information retrieval models for text documents searching due to its ability to represent documents into a computer interpretable form. Thus, VSM has a high degree of success and many researchers have focused on improving its traditional version [11]. In terms of VSM, the weight of term $t$ in document $d$ refers to its capability of distinguishing that document. The most frequent term in $d$, and least frequent in the entire document-space is the one most capable of distinguishing $\mathrm{d}$. Sometimes, however, this may not be the case since the actual distinguishing concept $c$ is defined via a set of terms scattered throughout the document in low frequency each.

This paper proposed a model for constructing an Arabic concept-space to be used as a VSM index. That enables the VSM to represent Arabic web documents by semantic vectors, in which the highest weights are assigned to the most representative concept. That permits a semantic classification of the Arabic web documents, and thus the semantic search abilities reflected in its precision and recall 0values can be obtained. The construction of the concept-space is based on the semantic relationships presented at the Universal WordNet (UWN) ${ }^{5}$. UWN is an automatically constructed multilingual lexical knowledge base based on WordNet. For over 1,500,000 words in over 200 languages, UWN provides a corresponding list of meanings and shows how such meanings are semantically related [12]. The evaluation of VSCAS system's retrieval effectiveness, a VSM search system, presented at [13], using the proposed concept-space index shows a noticeable enhancement against its performance using the traditional term-space.

The rest of this paper is organized as follows: Section II briefly describes how the use of concepts improves the performance of the VSM. Section III states the features of the proposed model in terms of the semantic expansion and then the concept-space generation. The next section represents the architecture of the model and its implementation details. The experimental results and discussion are detailed at Section V. Finally, the paper is concluded at Section VI.

1 swoogle.umbc.edu/

2 www.hakia.com

3 www.SenseBot.com

4 www.deepdyve.com

$5 \mathrm{http}$ //www.mpi-inf.mpg.de/yago-naga/uwn/downloads.html

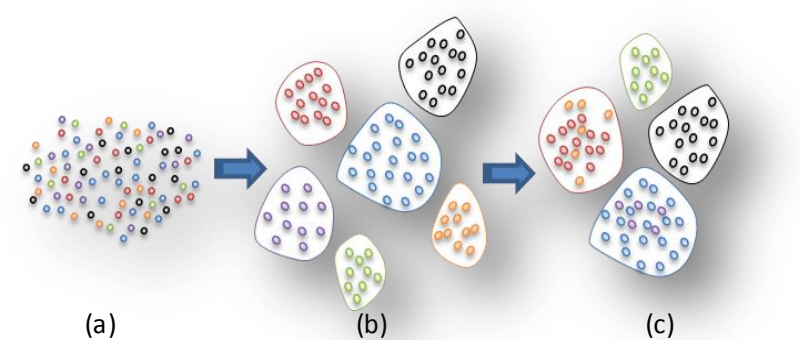

(a) Spread T erms - Space

(b) Clustered Terms into Concepts-Space (Level 1)

(c) Shrieked Concepts-Space (Level 2)

Fig. 1: Term-space to Concept-space

\section{Concepts and Semantic VSM}

In Semantic Web, the terms are used to explain concepts and relationships, i.e., the concepts are identified by the meaning shared by the related terms [14]-[15]. When these terms are used separately to establish a term-space, as in the case of the traditional syntactic VSM, the definition of their corresponding concepts will be lost through the term-space, fig.1 (a), and thus the generated vectors will stray in the space between them, fig.2 (a) and (b). Moreover, the most frequent term in the document may not be the most expressive one. The documents normally have a central concept, indicated by a group of related-terms, which together can describe the document better. Therefore, the document's vector is accurately directed if its highest weight is assigned to its central concept. That can only be achieved if the concepts can be defined, and then used as a semantic index of the VSM. For that end, the term-space has to be compressed into its equivalent concept-space. That eliminates the dispersion and accumulates the weights of the separate terms to get effective weights for the corresponding descriptive concepts.

Table 1: Term-space vs. Concept-space VSM

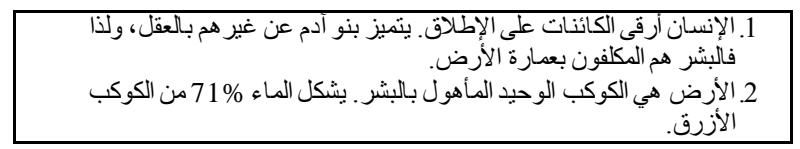

\begin{tabular}{|c|c|c|c|c|c|c|c|}
\hline & \multirow{2}{*}{ Term } & \multicolumn{2}{|c|}{$\begin{array}{c}\text { Term } \\
\text { frequency }\end{array}$} & \multirow{2}{*}{$\begin{array}{c}\text { Document } \\
\text { frequency } \\
\text { df }\end{array}$} & \multirow{2}{*}{$\begin{array}{c}\mathrm{IDF}=\log \\
4 / \mathrm{df}\end{array}$} & \multicolumn{2}{|c|}{$\begin{array}{c}\text { Term } \\
\text { weight }\end{array}$} \\
\hline & & d1 & d2 & & & d1 & $\mathrm{d} 2$ \\
\hline \multirow{6}{*}{$\begin{array}{l}\text { Term- } \\
\text { space } \\
\text { VSM }\end{array}$} & الإنسـان & 1 & 0 & 1 & 0.6 & 0.6 & 0 \\
\hline & بني ادم & 1 & 0 & 1 & 0.6 & 0.6 & 0 \\
\hline & البُشر & 1 & 1 & 2 & 0.3 & 0.3 & 0.3 \\
\hline & الارض & 1 & 1 & 2 & 0.3 & 0.3 & $Q 3$ \\
\hline & الأزورب & 0 & 1 & 1 & 0.6 & 0 & 0.6 \\
\hline & كوكب & 0 & 1 & 1 & 0.6 & 0 & 26 \\
\hline \multirow{3}{*}{$\begin{array}{l}\text { Concept- } \\
\text { space } \\
\text { VSM }\end{array}$} & إنسان & 3 & 1 & 2 & 0.3 & 0.9 & 0.3 \\
\hline & الأرض & 1 & 2 & 2 & & $0 . \overline{3}$ & 0.6 \\
\hline & كوكب & 0 & 1 & 1 & 0.6 & 0 & 0.6 \\
\hline
\end{tabular}

For more clarification, follow the case presented at table 1. The first two documents, of a four-document 
space, are presented at the top of the table. The terms presented at the table are instantiated only in these two documents. The first document is mainly related to the concept 'الإنسان' while the second is related to 'الأرض'. The results of a term-space-based VSM have the following defects:

- The highest weights of doc.1 are assigned to both: 'الإنسان', which means that the vector's angle will mediate these two terms instead of being sharply aligned to the most relevant term, or hence concept, see Fig.2 (a). This is also the case of doc.2 with the two terms 'كوكب', Fig.2 (b).

- While the term 'بشر' is referring to the main topic of doc.1, but it takes the same value with the term 'الأرض'. That means it has the same power of representing the doc.1 as the word 'الأرض', which is a mistake. This is obvious in the vector of doc. 1 at Fig.2 (a), which has an obtuse angle from the axis of 'بشر'. This case is also appearing in doc.2 for the terms 'كوكب', 'الأرض' look at the vector of doc.2 at Fig.2 (b). That means that if the user uses the word 'بشر' to get results, so doc.1 will be ranked lower than that if he uses the word 'إنسان', which is directly affecting the recall. Moreover, the word 'الأرض' has the same weight in both documents, which means that if the user uses the word 'الأرض' in the query, both doc.1 and doc.2 will have the same rank while the doc. 2 must achieve a higher rank. This case affects the precision.

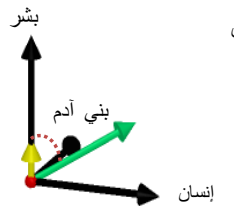

(a)

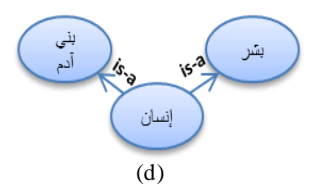

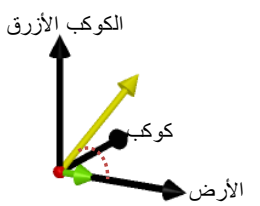

(b)

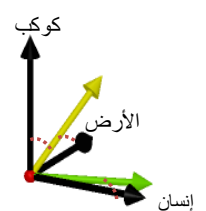

(c)

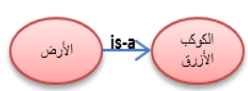

(e)

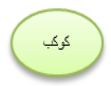

(f) (a) and (b) are two projections of 3D-Vector Space. That's for the simplification of representing 6-terms-space. (c) Represents the conversion of 6-terms-space into just 3-concepts-space. (d), (e), and (f) are Conceptual representations for the generated Concepts: 'الأرض', 'إنسان', and 'كوكب'

Fig. 2: Concepts and Vectors.

These problems are clearly avoided using the concept-space based VSM presented at the second part of the table. The six terms are grouped to produce just 3 concepts as presented at Fig.2 (d), (e), and (f). The representative concepts for each document receive the highest weights. Therefore, when the user asks for pages about 'البشر' or 'بني آدم', then doc.1 will be returned as the most relevant. Also, doc.2 will be more as sociated to the concept 'أرض' than doc.1.
In terms of vectors, this is interpreted to a clear alignment of each document to its representative concept by means of both angle and length. Also, it is clear that the vector of doc. 2 is mediated between the two concepts: 'الأرض' and 'كوكب since both of them is representing it. By doing so, the concept becomes better able to represent the documents, which is the purpose of the research.

\section{Features of the Proposed Model}

In order to construct the concept-space dictionary, a traditional term-space is established first, and then converted into its corresponding concept-space. The essential tool used to extract the term-space from a given document-space is the $\mathrm{RDI}^{6}$ Morphological Analyzer (Swift ${ }^{\circledR}$ ). Swift is mainly used to identify all morphological derivations occurrences of the currently processed term. These occurrences are stored at the database and then eliminated fro $m$ the documents -space to not be encountered anymore, and thus, terms redundancy is avoided. Once the term-space is generated, terms will be expanded using the UWN into three expansion types; Synonyms, Generalization properties, and Specialization properties. The UW $\mathrm{N}$ had been navigated just for the first depth of each expansion type. Each expansion is returned along with its confidence, which is used to give the expansion an appropriate degree of relevance to the original term. The UWN had been invoked by 29 different Arabic dialects ${ }^{7}$ in order to get the maximum possible expansions, since each dialect has its own set of expansions that may not be shared with other dialects. The redundant expansions are discarded with retaining those of the highest confidences.

\subsection{Semantic Expansion}

The first part of this section discusses how the synonyms affect the system while the second is dedicated for explanations about Generalization and Specialization properties.

\subsubsection{Synonyms Usage}

The proposed model exploited the synonyms in two main stages. The first stage is the semantic expansion of the term-space, as sampled at table 2 . The system treats the synonyms as equivalents to the original term, and thus their morphological derivations have the same relevance degree to the term as those of the term itself,

6 http://www.rdi-eg.com/

7 The 29 dialects are those at: http://www.sil.org/iso639-3/codes.asp, which have the following codes:

aao, abh, abv, acm, acq, acw, acx, acy, adf, aeb, aec, afb, ajp, ajt, aju, apc, apd, ara, arb, arq, ars, ary, arz, auz, avl, ayh, ayl, ayn, and ayp. Note that 'arb' is the code of the Standard Arabic. 
see table 3. The synonyms are also used at the stage of concept-space generation, in which they are used as indicators to the terms that have a shared sense, and thus can be used to define a corresponding concept.
This is declared in detail at the section of ConceptSpace Generation.

Table 2: Synonyms Sample

\begin{tabular}{|c|c|c|}
\hline Term Id & Term & Synonyms \\
\hline 1 & 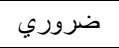 & أساسي, جو هري, هام, ملزم, حيوي, إجباري \\
\hline 2 & و وابل & مطر غزير, شؤبوب, طوفان \\
\hline 3 & 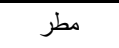 & ماطر, ممطر \\
\hline 4 & فيضان & طوفان, غمر , إغراق,زيادة تدفق \\
\hline 5 & الأم & و الدة, أح, الو الدة \\
\hline 6 & تنافر & تنافر , تهكم, تعارض, سخرية \\
\hline 7 & الملابس & ثياب, هدو م, كسوة \\
\hline 8 & إجتهد & كافح, حرص, ناضل \\
\hline 9 & الإنسان & آدمي, بشري, ابن آدم, ناس \\
\hline 10 & الطاقة & كهرباء,طاقة نووية \\
\hline 11 & عمل & شغل, مهنة, مشروع \\
\hline 12 & مشروعات & مؤسسة, شركة, شر اكة, عمل \\
\hline 13 & شغل & يستعمل, يستخدم, مهنة, عمل \\
\hline 14 & وظيفة & مهنة \\
\hline 15 & جسد & جسد, جيفة, جثة, جثمان \\
\hline 16 & هدية & هديةً, التبر ع, مو هبة, قريحة \\
\hline 17 & معدة & معدة, بطن, جوف \\
\hline
\end{tabular}

Table 3: Samples of Terms Synonymous Equivalents

\begin{tabular}{|c|c|c|}
\hline Term & Synonyms & Equivalent Expansions \\
\hline 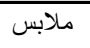 & ثياب, هدوم, كسوة & ملابس, لبس, ملبوس, ثوب, ثيلب, أثثاب, كسوة, يكسو, كساء, هدوم, ... \\
\hline الإنسان & آدمي, بشري, ابن آدم, ناس & آدمي, آدميون, بني آدم, بنو آدم, ناس, بشر بشري, ... \\
\hline عمل & شغل, مهنة, مشروع & يشتغل, شغل, مشاغل, عامل, عمل, مهن, يمتهن, مشاريع, مشروع, ... \\
\hline
\end{tabular}

Table 4: UWN Generalization and Specialization Samples

\begin{tabular}{|c|c|c|c|}
\hline Id & Term & Expansion Type & Expansions \\
\hline \multirow{2}{*}{1} & \multirow{2}{*}{ الجو } & Super-Classes & طقس \\
\hline & & Sub-Classes & ضباب \\
\hline 2 & الإنسان & Sub-Classes & جيل, عالم, بشر \\
\hline \multirow{2}{*}{3} & \multirow{2}{*}{ عمل } & Sub-Classes & مهنة, مكان, وظيفة, بيت, مؤسسة, شركة تجارية, مشروع, شر اكة, وكالة, تعاوني \\
\hline & & Super-Classes & فعل, مشروع, مأذون, مؤسسة, شر اكة \\
\hline 4 & 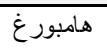 & Instance-Of & عاصمة, ميناء \\
\hline 5 & جزيرة & Has-Instance & قبرص, هايتي, برمو دا, جامايكا, أوكيناو ا, مالطا, جزر كناري, ... \\
\hline 6 & مكان & Sub-Classes & منطقة, أدغال, الأرض, فضاء, مساحة \\
\hline \multirow{2}{*}{7} & \multirow{2}{*}{ 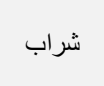 } & Sub-Classes & مشرو بات غازية, لبن, حليب, شوكولاته, عصير, فنجان شاب, قهوة \\
\hline & & Super-Classes & محلول, أكل, مأكل \\
\hline
\end{tabular}

The synonyms vary in their degree of identification with the original term's meaning. Therefore, the confidence of each is used to precisely determine how their instances should increase the overall term's frequency $\mathrm{tf}_{\mathrm{ij}}$. For example, the synonym 'تعارض' of the term 'تنافر' is more relevant than the synonym'تهكمرض'.

\subsubsection{Generalization and Specialization Properties}

Other types of semantic expansions are those for generalization properties (Super-Classes and Instanceof) and specialization properties (Sub-Classes and HasInstances). These types of expansions are used as indicators of an indirect relevance to the term. I.e., if the 
user searches for a term that is not directly found in the documents-space, the system can find generalized or specialized results using these kinds of expansion. These expanding types may also be used as Named Entities extractors. For example, the term 'هامبور غن', at table 4, is an instance of both 'عاصمة', and 'ميناء', which

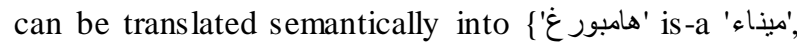

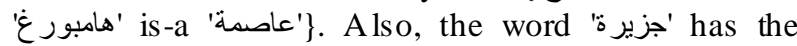

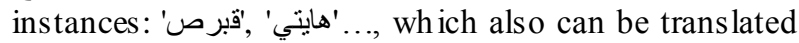

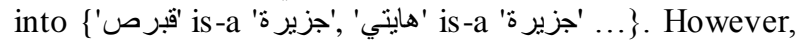
the UWN is still not fully filled with Arabic Named Entities; that is why the Arabic Named Entity Extractor ANEE [16] is used instead.

\subsection{Concept-Space Generation}

The term-space is converted into a concept-space via two shrinking levels as described below.

\subsubsection{Term-Space Direct Shrinking (Level 1)}

This level of shrinking aims to integrate all terms sharing one or more synonyms into just one comprehensive concept. For more declarations, refer to items 2 and 4 at table 2, each of which has a different list of synonyms unless the shared one: 'طوفان'. That means that they can be merged to develop a concept gathering all synonyms of both terms as presented in table 5. The terms $11,12,13$, and 14, at table 2, are another example of the direct shrinking process. The term 'عمل' has three synonyms as 'شغلة', 'مهرو' 'مشرو'. The synonym 'شغل' itself is another term in the termspace, so these terms along with their synonyms will be directly shrieked. The other synonym, 'مشروع', is also found in the term space as its derivation 'مشروعات' Therefore, they will be shrieked also. The third synonym 'مهزه' is matched with a synonym of another term 'وظيفة'. Consequently, these four terms will be shrieked to establish the concept 'عمل' represented at table 5. This way, the terms can be merged to get a richer definition using the full set of their describing items as depicted in Fig. 1 (b). That gives the concept a firm definition and thus a higher weight, which is exactly what is intended by this research. That high weight is the power that pulls the vectors of the germane topics to the right direction as presented in Fig.2 (c).

Table 5: Direct Shrinking Samples

\begin{tabular}{|c|c|}
\hline New concept & Concept's Definition \\
\hline 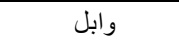 & غمر, إغراق,ز يادة تدفق مطر غزير, شؤبوب, طو فان \\
\hline 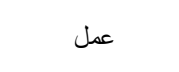 & يستعمل, يستخذر مشروع, مؤسسة, شركة, شر اكة, عمل, \\
\hline
\end{tabular}

\subsubsection{Term-Space Indirect Shrinking (Level 2)}

The subsequent shrinking level is applied on the case of the transitive expansions. For example, if term $\mathrm{A}$ is a synonym of term $\mathrm{B}$, which in turn is a synonym of term $\mathrm{C}$, then the terms $\mathrm{A}$ and $\mathrm{C}$ are belonging to the same concept. For example, the third term at table 6, 'لغة', is one of the synonyms of the fourth term 'لسان', so they will be directly shrieked. Likewise, the word 'كلام' is a synonym of the terms 'بيث', 'حديث', , لغةن', so they are considered as direct synonyms to 'لغة', and indirect synonym to 'لسان', and so on. This process generates a list of distinct concepts-space in which no two concepts are overlapped as presented in Fig. 1 (c).

Table 6: Indirect Shrinking Samples

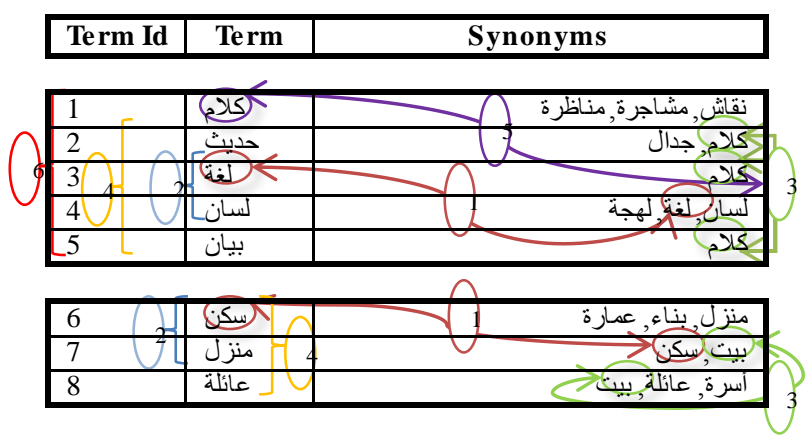

\section{Architecture and Implementation Details}

This section describes the architecture of the model used to extract an Arabic concept-space from Arabic Wikipedia. The architecture is depicted in Fig. 3.

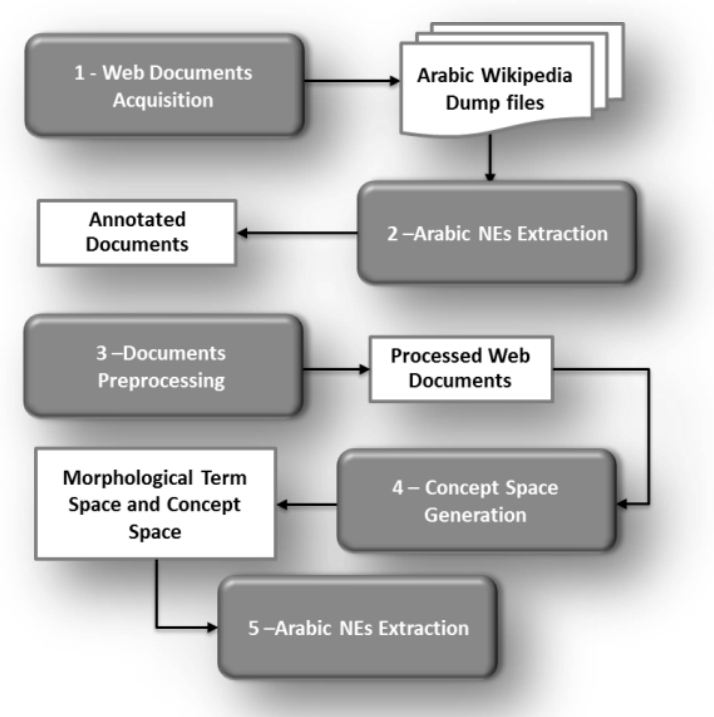

Fig. 3: Concept-space Generation Model

\subsection{Web Documents Acquisition}

This is the process of capturing the Web documents to be used as the source of knowledge. The acquired documents are extracted from a full Arabic Wikipedia dump ${ }^{8}$. The statistics of the acquired documents are described at table 7 below.

\footnotetext{
${ }^{8}$ The used Arabic Wikipedia dump is the version of 29-Aug-2012, and it is downloaded from: http://dumps. wikimedia.org/arwiki/
} 
Table 7: Acquired Documents Statistics

\begin{tabular}{|c|c|c|}
\cline { 2 - 3 } \multicolumn{1}{c|}{} & All Articles & Average per Article \\
\hline Count of Articles & 234,208 & - \\
\hline Count of Sentences & 1952024 & 171 \\
\hline Count of Words & 40111545 & 1293 \\
\hline Count of letters & 302817233 & 9 \\
\hline Extracted Named Entities & 2146884 & 8 \\
\hline
\end{tabular}

\subsection{Named Entities Extraction and Annotation}

A named entity is a phrase that clearly identifies one item from a set of other items that have similar attributes. Examples of named entities are first and last names, geographic locations, ages, phone numbers, companies, organizations and addresses. ANEE [16] is capable to recognize Arabic Named Entities of types: Person, Location, Organization, Time, Number, Measurement, Percent, and File name. Nevertheless, just the first three types of annotations were used since the numbers cause some problems with the Arabic
Morphological Analyzer Swift. The first main reason for extracting the named entities is to keep them out of any text preprocessing since some of them may include stop words or non-Arabic letters. The second reason is to send them out to the UWN to be expanded for their other aliases if they have any. Figure 4 presents a sample of the ANEE results. As presented in table 7, the overall number of extracted NEs is 2146884 , with an average of 9 NEs per Wikipedia Article.

\begin{tabular}{|c|c|c|c|c|c|c|c|}
\hline 田 & الاتحاد الدولى للاتصالات & Organization & 田 & فارسـى & Location & جول & Person \\
\hline 田 & مصر & Location & 田 & صافى & Person & الفيروسـات & Location \\
\hline 田 & القاهرة & Location & $\boxplus$ & الموصل ، & Location & هيكا، & Person \\
\hline 田 & رامر الله & Person & $\boxplus$ & عصبية & Location & ن, & Person \\
\hline 田 & فلسطير: & Location & $\boxplus$ & الأجرامر السماوية & Location & ليفنى & Person \\
\hline 田 & طرف & Person & 田 & أحمد مسمد & Person & الصور & Location \\
\hline 田 & أنطونيو & Person & 田 & 190 & Location & جيمسر & Person \\
\hline 田 & الكونجر سر ، & Organization & $\boxplus$ & لأينشتايرi & Person & القاعدة & Organization \\
\hline 田 & رئيسة & Person & 田 & أينشتايرن & Person & الكونى & Location \\
\hline 田 & التلفونى & Location & $\boxplus$ & اليابان & Location & كونى & Location \\
\hline 田 & الكر بونى & Location & 田 & الحياة & Organization & مسلم & Person \\
\hline 田 & رقيقة & Person & 田 & : مصدرا & Person & الميكرونى & Location \\
\hline 田 & المملكة المتحدة & Location & 田 & ألبرت أينشتايرا & Person & عالية & Person \\
\hline 田 & أستر اليا & Location & 田 & وتر وسر ו & Location & هانز & Person \\
\hline 田 & وماليزيا & Location & 田 & أمر يكا & Location & اندريه & Person \\
\hline 田 & وجنوب أفر يقيا & Location & 田 & هولندا & Location & ماري & Person \\
\hline 田 & الهند & Location & 田 & المناطو ، & Location & مايكرا , & Person \\
\hline 田 & هونج كونج & Location & $\boxplus$ & فرنسا & Location & فيليب رايسر ) & Person \\
\hline 田 & ولندن & Location & 田 & بنى & Location & مصباح & Person \\
\hline 田 & ونيويور ك & Location & 田 & الحديثة & Location & نيكولا & Person \\
\hline 田 & وطوكيو & Location & 田 & شمسح & Person & ألمانيا & Location \\
\hline 田 & بالولايات المتحدة & Location & 田 & المبنى & Location & مار كونى & Location \\
\hline 田 & ونيوز يلندا & Location & 田 & ثابت & Person & جون & Person \\
\hline 田 & nlc & Person & $\boxplus$ & كواكب & Person & نيويورك & Location \\
\hline
\end{tabular}

Fig. 4: ANEE's Results Sample

\subsection{Annotated Documents Preprocessing}

This module is constructing the system's documents space $A W D S$ as defined at Def.1.

\section{Def.1: Arabic Wikipedia Document-Space (AWDS) and Named Entities List (NEs)}

Given Arabic Wikipedia's dump files Dump, the Documents Space of the system, $A W D S$, is produced by processing the Dump files as follows:
1. Converting Dump into txt files using WP2TXT application,

2. Convert .t xt files to Annotated XML files using ANEE,

3. Split XML files into set of separate articles

$A=\left\{a_{1}, a_{2}, \ldots, a_{i}, \ldots, a_{n}\right\} ;$ where :

$n=$ \#articles in Dump, and $a_{i}=$ article $i$. 
4. Clean $A$ from any non-Arabic letters \& A rabic stopwords, keeping the annotation tags.

5. Extract all NEs along with their categorization in NEs List.

That will generate both $A W D S$ and NEs, which are defined as:

a. $A W D S=\left\{\mathrm{d}_{1}, \mathrm{~d}_{2}, \ldots, \mathrm{d}_{\mathrm{i}}, \ldots, \mathrm{d}_{\mathrm{n}}\right\}$, where $\mathrm{d}_{\mathrm{i}}$ is an annotated preprocessed Arabic Wikipedia document.

b. NEs is the set of all Named Entities in AWDS, as

$N E s=\left\{\mathrm{Ne}_{1}, \mathrm{Ne}_{2}, \ldots, \mathrm{Ne}_{\mathrm{i}}, \ldots, \mathrm{Ne}_{\mathrm{n}}\right\}$, where:

- $N e_{i}=\left\{n e_{i 1}, n e_{i 2}, \ldots, n e_{i j}, \ldots, n e_{i m}\right\}$

- $m=$ \# named entities in Article $i$

- $n e_{i, j}=n e($ name, category)

- category $=\left\{\begin{array}{c}P, \text { entity is a Person } \\ L, \text { entity is a Location } \\ O, \text { entity is a Organization }\end{array}\right.$

\subsection{Concept-Space Generation}

This process is the core of the model, by which the concept-space index is produced. In order to be accomplished, the traditional Arabic Morphological Term-Space MTS is firstly constructed, as detailed at Def. 2 and Algorithm 1. Then the MTS is semantically expanded using the UWN as presented in Def.4. The terms are then grouped into concepts via two levels of shrinking as described in Def.5 and Algorithm 2. The main motive of using the UWN instead of the Arabic WordNet is its ability to return the expansions of a given word in many dialects. Moreover, its universality enables the use of translation tools in order to get the expansions of the words that have no expansions in Arabic. The last process is searching documents using the VSM based semantic Search System, VSCAS [13].

\section{Def. 2: Morphological Term-Space (MTS)}

The MTS of the model is defined as the set of all distinct terms that belong to the AWDS.

MTS $=\left\{\mathrm{Mt}_{1}, \mathrm{Mt}_{2}, \ldots, \mathrm{Mt}_{\mathrm{i}}, \ldots, \mathrm{Mt}_{\mathrm{k}}\right\}$, where:

$\mathrm{Mt}_{\mathrm{i}}=$ set of morphological derivations of ite $\mathrm{m} \mathrm{i}$ in the MTS as:

$$
\begin{aligned}
& M t_{i}=\left\{t_{i 1}, t_{i 2}, \ldots, t_{i j}, \ldots, t_{i m}\right\} ; \\
& k=\# \text { items in MTS; } \\
& m=\# \text { derivations of item } i .
\end{aligned}
$$

\begin{tabular}{ll}
\hline Algorithm 1: MTSGeneration \\
\hline 1. Input: \\
2. AWDS \\
3. Output: \\
4. MTS \\
5. Functions and Variables: \\
\hline
\end{tabular}

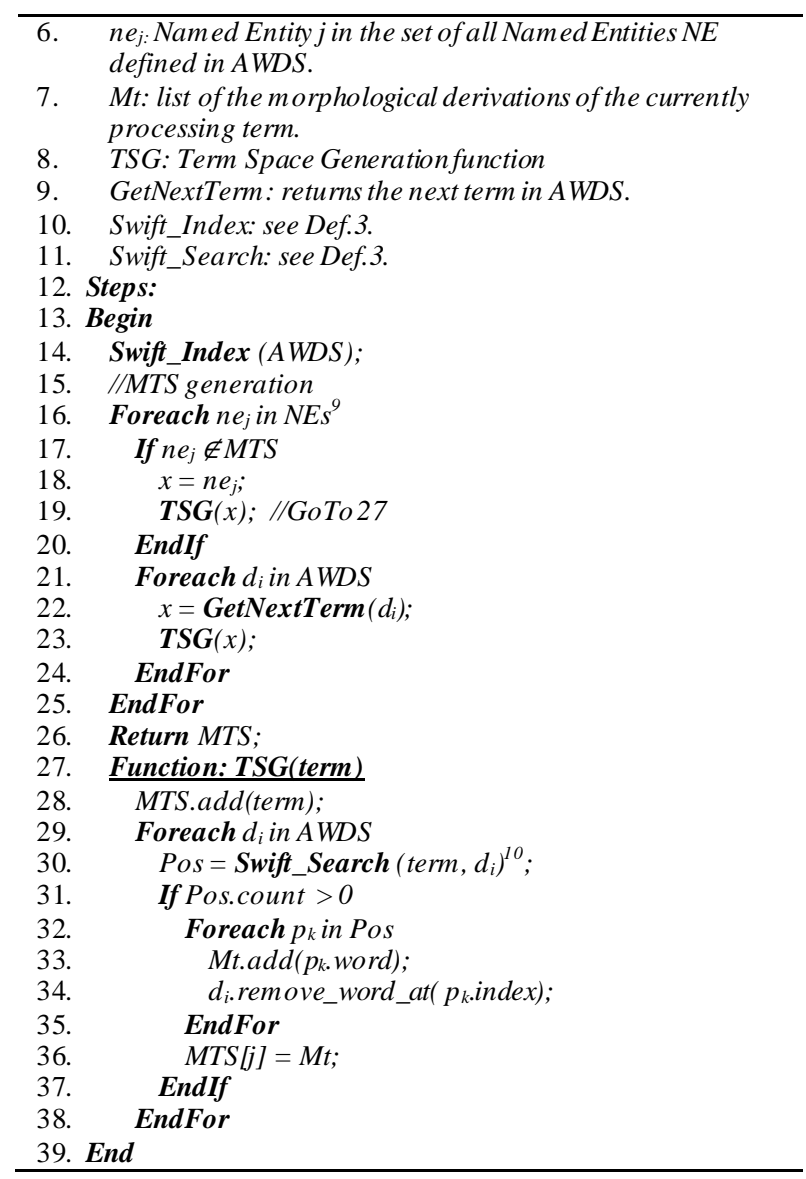

\section{Def.3: Swift Indexing and Searching ${ }^{11}$}

The indexing function of Swift is defined as:

$$
d x=\text { Swift_Index (scope) } .
$$

Where, scope's indexes are saved at $d x$.

The searching function is defined as

$$
\text { Pos }=\text { Swift_Search }(x, \text { scope })
$$

The searching function finds morphological occurrences of $x$ within the scope.

Pos: list of words/positions pairs that matched the term $x$ in the scope.

\section{Def. 4: Semantic Terms-Space (STS)}

Given MTS, a java application ,using UW N library ${ }^{12}$, Princeton WordNet plugin ${ }^{13}$, and UWN Core plugin, is built ${ }^{14}$ in order to expand MTS to get the semantic

\footnotetext{
${ }^{9}$ The Multi-Words Named Entities are taken into consideration.

${ }^{10}$ Using RDI Swift Searcher.

${ }^{11}$ Using RDI Swift Indexer.

${ }^{12}$ Updated version that allows you to obtain statement weights and fixes a character encoding issue. It is updating according to Aya AlZoghby's report at (2012-11-23):

http://www.mpi-inf.mpg.de/yago-naga/uwn/uwnapi.zip

${ }^{13} \mathrm{http}$ //www.mpi-inf.mpg.de/yago-naga/uwn/wordnet.zip

${ }^{14} \mathrm{http}: / /$ www.mpi-inf.mpg.de/yago-naga/uwn/uwn.zip
} 
term-space STS. The expansion function is defined as follows:

$$
\begin{aligned}
& \text { expand }\left(t_{i}\right)=\left\{S_{i}, U_{i}, P_{i}, H_{i}, I_{i}\right\}, \\
& S t_{i}=\text { expand }\left(t_{i}\right) \cup M_{i} \\
& S T S=\left\{S t_{1}, S t_{2}, \ldots, S t_{i}, \ldots, S t_{k}\right\}, \text { where: } \\
& k=\# \text { items in MTS; } \\
& M_{i}=M t_{i} \text { that is alreadydefined at Def. } 2, \\
& S_{i}=\left\{s_{1}, \ldots, S_{a}\right\}, / / \text { synonyms } \\
& U_{i}=\left\{u_{1}, \ldots, u_{b}\right\}, / / \text { Sub-Classes } \\
& P_{i}=\left\{p_{1}, \ldots, p_{c}\right\}, \quad / / \text { Super-Classes } \\
& H_{i}=\left\{h_{1}, \ldots, h_{d}\right\}, / / \text { Has-Instances } \\
& I_{i}=\left\{i_{1}, \ldots, i_{e}\right\}, \quad / / \text { Instances-of }
\end{aligned}
$$

Each expansion of $s, u, p, h, \&$ i, is represented as a pair of expansion-word and expansion-confidence on the form exp $=$ (word, conf.)

\section{Def. 5: concept-space (CS)}

Given STS, all items that are representing the same concept are grouped in order to generate the conceptspace which is defined as follows:

$$
C S=\left\{C_{1}, C_{2}, \ldots, C_{q}\right\}, \text { where: }
$$

$\mathrm{q}=$ \# concepts extracted from c items of the STS;

$\mathrm{C}_{\mathrm{i}}=$ the concept $\mathrm{i}$ that is defined by set of items of STS as follows:

$$
\mathrm{C}_{\mathrm{i}}=\left\{\mathrm{st}_{\mathrm{i} 1}, \mathrm{st}_{\mathrm{i} 2}, \ldots, \mathrm{t}_{\mathrm{ij}}, \ldots, \mathrm{st}_{\mathrm{ic}}\right\} ; \text { where: }
$$

$s t_{i j}=$ the semantically expanded item $\mathrm{j}$ representing the concept $i$.

$$
c=\# \text { items that defined the concept } i \text {. }
$$

\section{Def. 6: Expansions-Merge}

The concept-space CS is finally generated by the application of the function Expansions-Merge on the CS items to merge the expansions of all participating in the definition of the concept $i$ in CS as follows:

$$
\begin{aligned}
\mathrm{C}_{\mathrm{i}} & =\text { Expansions-Merge }\left(\left\{\mathrm{st}_{\mathrm{i} 1}, \mathrm{st}_{\mathrm{i} 2}, \ldots, \mathrm{st}_{\mathrm{i} j}, \ldots, \mathrm{st}_{\mathrm{ic}}\right\}\right) \\
& =\text { Expansions-Merge }\left(\left\{\left\{\mathrm{M}_{\mathrm{i} 1}, \mathrm{~S}_{\mathrm{i} 1}, \mathrm{U}_{\mathrm{i} 1}, \mathrm{P}_{\mathrm{i} 1}, \mathrm{H}_{\mathrm{i} 1},\right.\right.\right. \\
\left.\left.\left.\mathrm{I}_{\mathrm{i} 1}\right\}, \ldots,\left\{\mathrm{M}_{\mathrm{ic}}, \mathrm{S}_{\mathrm{ic}}, \mathrm{U}_{\mathrm{ic}}, \mathrm{P}_{\mathrm{ic}}, \mathrm{H}_{\mathrm{ic}}, \mathrm{I}_{\mathrm{ic}}\right\}\right\}\right) & \\
\mathrm{C}_{\mathrm{i}} & =\left\{\mathrm{M}_{\mathrm{i}}, \mathrm{S}_{\mathrm{i}}, \mathrm{U}_{\mathrm{i}}, \mathrm{P}_{\mathrm{i}}, \mathrm{H}_{\mathrm{i}}, \mathrm{I}_{\mathrm{i}}\right\}
\end{aligned}
$$

\begin{tabular}{ll}
\hline Algorithm2: Concept-Space Generation \\
\hline 1. & Inputs: \\
2. & STS. \\
3. & Outputs: \\
4. & CS. \\
5. & Functions and Variables: \\
6. & T: Set of all term in STS \\
7. & S: Set of all synonyms of all terms in STS \\
8. & G: List of groups of terms that are directly clustered \\
\hline
\end{tabular}

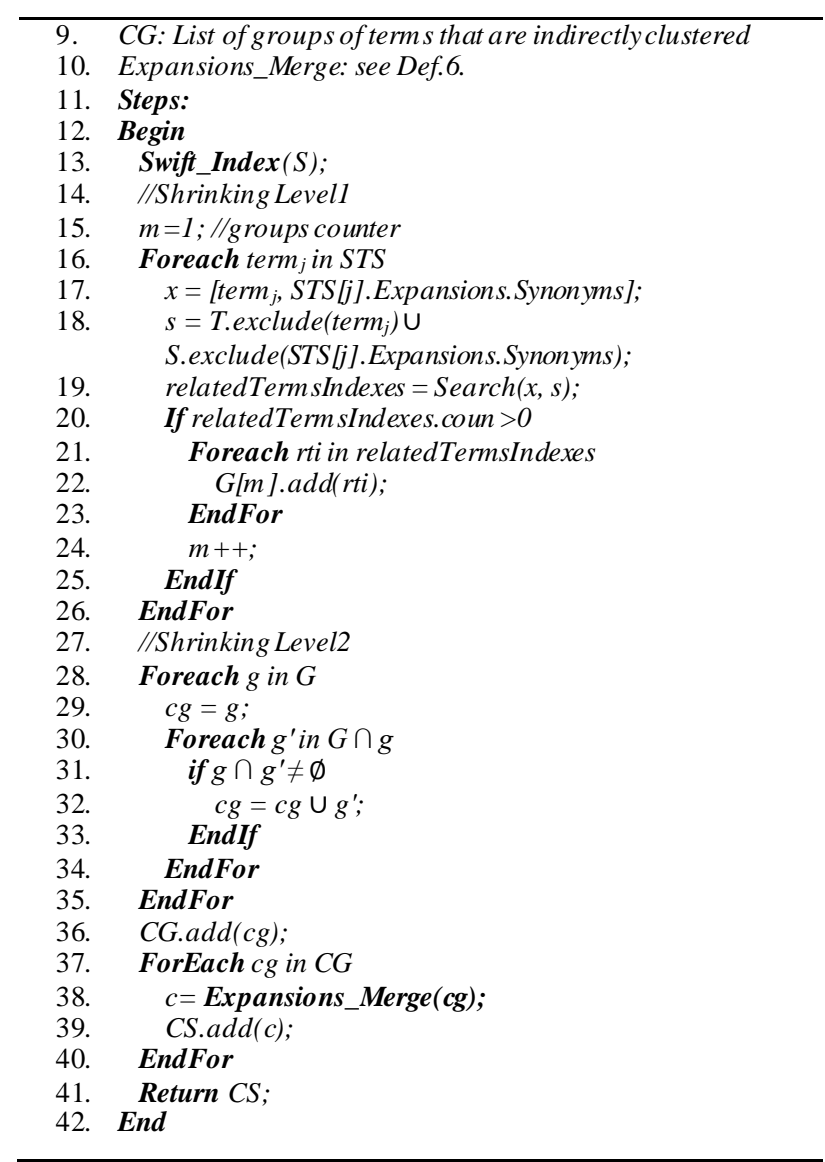

\section{Results and Discussion}

This section discusses the experimental results along with implementation limitations affecting them.

\subsection{Experimental Results}

\subsubsection{Generated Concept-Space}

From the $A W D S$, a term-space of 391686 terms is extracted, 31200 of which are NEs. Each extracted term is enclosed with its set of derivations that occurred in the document space, with an average of 102 derivations each. The term-space is then expanded via UWN with 191442 total expansions; $12 \%$ of them are in the form of phrases. The shrinking algorith $m$ is then executed to generate a concept-space of 223502 concepts from the term-space, excluding NEs set, by compression ratio of $62 \%$. The ampler concept is defined by 66 merged terms while the tighter one is just of two. Some of the terms are never merged; most of the mare NEs, strange, or misspelled words. The first shrinking level generated 299203 groups of terms from the 360486 terms. The second level then condensed them into just 223502 groups, each of which defines a distinct concept.

\subsubsection{VSM Search System Results}

The demonstrated model is evaluated by measuring its impact on the effectiveness of the VSM search 
system, VSCAS [13], in terms of precision, recall, and F-Measure. To do so, the VSCAS is executed three times with the same query; 'ما هي مصادر الطاقة ؟', but different indices; MTS, STS, and CS. The query is preprocessed and then expanded to be:

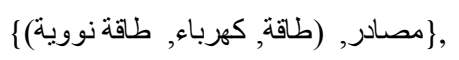

It is then conceptualized into:

$$
\text { (طاقة, كهرباء, طاقة نووية, بنرول, نفط, حرارة, خلايا شمسية) }
$$

For calcu lating the system's recall, a sample of 200 documents is randomly selected, reviewed for relevancy, and then used as the documents-space of the three experiments. The experimental results showed the following:

- The highest precision's percentage was that of the experiment that used the MTS as its index. This is because, in this case, the unrelated, yet retrieved, pages are just those that have the words 'مصادر', and

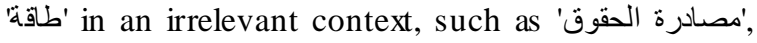

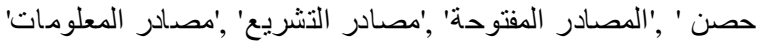
'طدينة طاقة',' 'طاق بستان', and 'طدانة', They are just 12 pages. However, despite its high precision, this experiment's recall is the lowest, since it ignored all those semantically relevant pages, which are 32 .

- The system's precision decreased in the second experiment; when it used the STS indexing. The main reason of that is the phrases' handling shortage, detailed at B-6. Owing to that shortage, the expanding phrase 'طاقة نووية' is treated as two words, and hence all documents related to the word 'طووي' solely are also retrieved. That yields the retrieval of documents about 'الإمام ','برنامج نووي', 'أحماض نووية النوي retrieved documents are increased by other 10 to be 22 documents in total. Nevertheless, the recall is increased since the missed relevant documents are decreased to be just 24 instead of 32, as 8 of them are semantically retrieved due to the expansions 'كهرباء', and 'طاقة نووية'.

- As for the third experiment, which used the conceptual index $C S$, the precision increased again, but not to the extent of the first case, since the phrase handling problem still affecting it. This time, the phrase 'خلايا شمسية caused the retrieval of additional 6

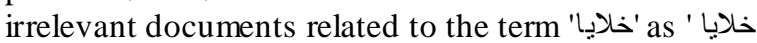
'خلايا نباتية', 'جذعية'... etc. However, the recall is increased to the extent that makes the F-Measure of this experiment the highest one. That is due to the semantic retrieval of most of the relevant documents. It just ignored 3 documents concerning 'إنشعاع', and 'حركة المياه', as these terms are not present in the concept's definition itself.

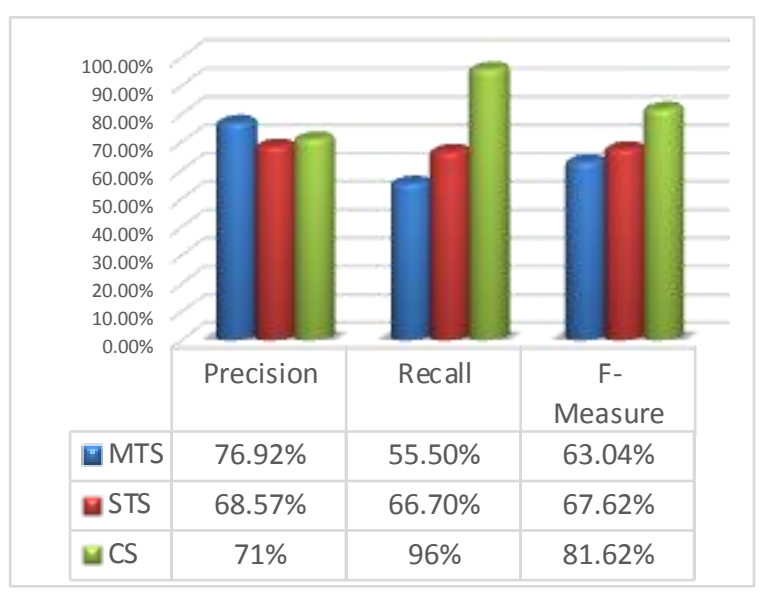

Fig. 5: The results of VSM Search System using three dictionaries: MT S: Morphological term Space, ST S: Semanticterm Space, and CS: Concept Space

\subsection{Implementation Limitations}

Using the proposed model has enhanced the performance of the VSM search system; however, there are many difficulties and limitations that affect the overall effectiveness. These limitations are discussed below.

\subsubsection{Arabic Language Processing Difficulties}

The Polysemy problem is one of the main difficulties affecting the operation of concepts extraction. The Polysemy problem means that the same keyword may have different meanings depending on its context or its vowelization as the word ' $מ-$ L $^{\prime}$. The non-vowelized form of the word 'طعم' is ambiguous between two words;

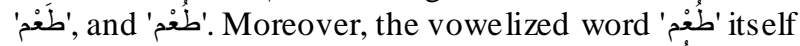
is contextually ambiguous. It may refer to 'طعُعْ' 'طعُم' 'طعْم' for ' decoy', or 'طُعْم' for 'vaccine'.

At the semantic expansion stage, the ambiguous term may be expanded with a wrong sense, and; therefore, it will be categorized as a wrong concept. This, consequently, will affect the shrinking process since the word will be grouped with others belonging to that wrong concept. For example, while the word 'طع', at table 8, contextually means 'طُعْ' for 'decoy', it is

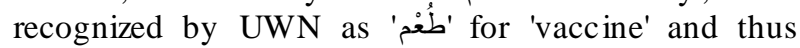
expanded to 'قاح'. Swift then aggravated the problem as it matched the morphological derivation 'طعميه' of the word 'طعم', means 'taste', to the word 'طعم' already expanded to 'decoy'. That generated a meaningless concept defined as فلافل, طعيه, لقاح, طعم\}.

Table 8: Polysemy and Ambiguity Problems

\begin{tabular}{|c|c|c|}
\hline Id & Term & Synonyms \\
\hline 1 & فلافل & لقعيه \\
\hline 2 & لقاح & - \\
\hline 3 & أستاذ, سيدي, حضرتك, أفندي \\
\hline 4 & سيدي \\
\hline
\end{tabular}


The Prefixes and Suffixes uncertainty yield other matching errors as presented in the second group of the table. The terms 'كندي' 'كيد' are grouped because the

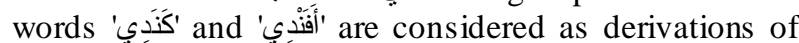

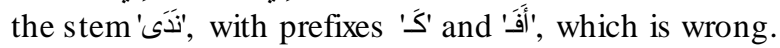

\subsubsection{Morphological Analysis Limitations}

The Swift module sometimes results in some indexing, and hence searching, errors. That causes the cancelation of several morphological occurrences of the terms, which yields redundant term-space.

However, the designed system solves this problem by grouping the redundant terms based on their shared synonyms. This case is sampled at table 9.

Table 9: Term-space Redundancy and synonyms Sharing Solution

\begin{tabular}{|c|c|c|}
\hline $\begin{array}{l}\text { Redundant } \\
\text { term-space }\end{array}$ & Synonyms & $\underset{\text { Merms }}{\text { Merging Redundant }}$ \\
\hline 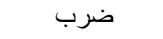 & ضرب & \multirow{4}{*}{ 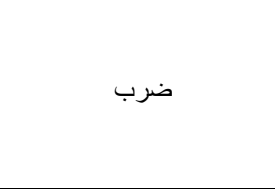 } \\
\hline 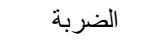 & ضرب & \\
\hline نضرب & ضرب & \\
\hline بضربات & ضرب اب & \\
\hline بحرص & اجتهذ كافح حرص ناضل & \multirow{3}{*}{ بحرص } \\
\hline حرصت & اجتهد كافح حرص ناضل & \\
\hline وتحرص & اجتهد كافح حرص ناضل & \\
\hline
\end{tabular}

\subsubsection{UWN Limitations}

UWN has some limitations that affect the system's results. The firs is related with the confidence value, which may give inaccurate or wrong impression about the relevance between a term and its expansion. It may give a low value for a highly confident expansion and the vice versa. Moreover, while the valid confidence value ranges between 0.0 and 1.0 , it sometimes exceeds that limit. That is due to the comb ination of information from two sources, according to Gerard de Melo [12], which togethergive more than 1.0.

Another issue is that not all UWN expansions are accurate. They sometimes are incorrectly categorized, while other times they are overlapped in different categories. Moreover, they may not be an expansion of the term at all. For example, at table 10:

1. The words 'جمارك' and 'استخدام' are not expansions to the term 'تقاليد'.

2. Even the word 'استخدام' is not a true expansion; it takes the highest confidence, which, to make things worse, exceeds 1.0 .

3. The word 'أكثر' is duplicated as a synonym for the term 'زيادة'. That comes from the use of different dialects; however, the redundant expansions must have the same confidence.
TABLE 10. UWN LIMITATIONS

\begin{tabular}{|c|c|c|}
\hline term & Expansions & Confidence \\
\hline \multirow[t]{2}{*}{ تقاليد } & جمارك & 0.78932524 \\
\hline & إبتخدام & $2 \quad 1.0747153$ \\
\hline \multirow[t]{2}{*}{ زيادة } & & 0.5178884 \\
\hline & أك大 & 0.50702417 \\
\hline
\end{tabular}

\subsubsection{NEs Extraction Limitations}

The performance of ANEE as a whole is acceptable; however, it has some deficiencies. The first is the extraction of non-NE as sampled in table 11-A. Also, the NEs may sometimes be misclassified, see table 11-B Moreover, it suffers from the contextual ambiguity, as presented in table 11-C. The last problem is the overlapping of categorization such as:

$$
\begin{aligned}
& \text { ويستعمل أرباب الصناعة حوالي } 10 \text { لترات من الماء لتكرير لتر واحد من }
\end{aligned}
$$

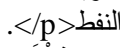

$$
\begin{aligned}
& \text { نسنحَب المصانع في >p> }
\end{aligned}
$$

>Person ><Location ><Organization>

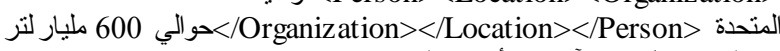
من الماء يوميًا من الآبار والأنهار والبحيرات

TABLE 11. ANEE LIMITATIONS

\begin{tabular}{|c|c|c|c|}
\hline \multirow{13}{*}{ 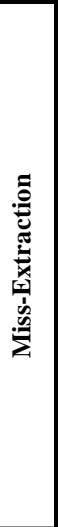 } & Named Entity & \multicolumn{2}{|l|}{$\begin{array}{c}\text { ANEE } \\
\text { Category }\end{array}$} \\
\hline & العربي الوحبد & \multicolumn{2}{|l|}{ Person } \\
\hline & معمر هي & \multicolumn{2}{|l|}{ Person } \\
\hline & تفصيلي زر اعة علم & \multicolumn{2}{|l|}{ Person } \\
\hline & رنين أو & \multicolumn{2}{|l|}{ Person } \\
\hline & نصيب الأسد & \multicolumn{2}{|l|}{ Person } \\
\hline & حركة الاطر اف ويستعمل عادة & \multicolumn{2}{|l|}{ Organization } \\
\hline & الحكومة الإير انية تسعى & \multicolumn{2}{|l|}{ Organization } \\
\hline & مجمو عة صور توضيحية & \multicolumn{2}{|l|}{ Organization } \\
\hline & للكيلو غر ام الواحد & \multicolumn{2}{|l|}{ Location } \\
\hline & بالكيروسين & \multicolumn{2}{|l|}{ Location } \\
\hline & للأور ام السرطانية & \multicolumn{2}{|l|}{ Location } \\
\hline & بحو الي & \multicolumn{2}{|l|}{ Location } \\
\hline \multirow{5}{*}{ 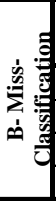 } & Named Entity & $\begin{array}{c}\text { ANEE } \\
\text { Category }\end{array}$ & $\begin{array}{c}\text { The Actual } \\
\text { Category }\end{array}$ \\
\hline & رام الله & Person & Location \\
\hline & مجلس الامن & Person & Organization \\
\hline & يهوذا & Location & Person \\
\hline & قنا & Organization & Location \\
\hline \multirow{10}{*}{ 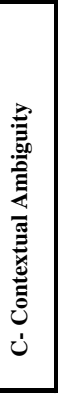 } & Named Entity & $\begin{array}{c}\text { ANEE } \\
\text { Category }\end{array}$ & $\begin{array}{c}\text { Contextual } \\
\text { Meaning }\end{array}$ \\
\hline & 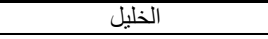 & Location & lover \\
\hline & القاعدة & Organization & rule, base \\
\hline & الفجر & Organization & daybreak \\
\hline & إعمار & Organization & reconstruction \\
\hline & رقيقة & Person & thin, fragile \\
\hline & صافي & Person & net, pure \\
\hline & كو اكب & Person & planets \\
\hline & 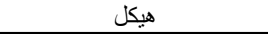 & Person & structure \\
\hline & صور & Location & photos \\
\hline
\end{tabular}

The NE 'الولايات الدتحدة' is categorized as Person, Location, and Organization. In this case, the outermost annotation is taken as the categorization result, which may sometimes be incorrect. 


\subsubsection{Wikipedia Misspellings}

Since Wikipedia is originally based on the community efforts, it sometimes contains misspelling errors, which are unrecognizable by neither UWN nor Swift, and thus cannot be conceptualized, even if they are crucial terms. These misspellings may be caused by the adhesion of two or more words as 'ؤكسيكا', 'ؤكسين',

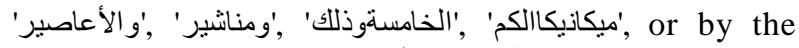

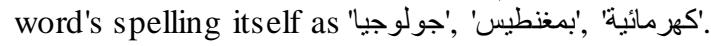

\subsubsection{Implementation Deficiencies}

The main defect of the system implementation is the capability of indexing and analyzing phrases. This shortage is the main reason for $C S$ and STS precisions' dropping. The set of all expansions of such term are collected in one sentence as a set of words separated by spaces to be indexed by Swift. This index is then used for searching for their morphological occurrences within the documents-space. Actually, this approach caused a problem in dealing with the phrasal expansions, since the phrase will not be identifiable from the rest of other words. So, for example, when the word 'طقة 'طوبة' was expanded to the phrase 'طاقة نووية', it was handled as two separate words. Consequently, the irrelevant documents about 'نووي' were retrieved, and; therefore, the precision is affected. In order to solve that problem, each expansion must be indexed as a standalone object, and thus the phrases will be discriminated, and will be searched for as a whole. However, the main hindrance of doing so is the excessive memory consumption caused by this indexing approach, which in turn hangs up the overall search process.

\section{Conclusions and Future Work}

Arabic Language is the mother tongue for 23 countries and more than 350 million persons. Nevertheless, it is still far from being semantically searchable. This paper proposes a model for producing an Arabic Concepts-Space to be used as the index of Semantic Vector Space Model. The Vector Space Model is one of the most common information retrieval models for textual documents, due to its ability to represent documents into a computer interpretable form. However, as it is syntactically indexed, its sensitivity to keywords reduces its retrieval efficiency. In order to improve its effectiveness, we proposed a model for extracting a concept-space dictionary, using the semantic ontology UWN, to be used as a semantic index instead of the traditionally used term-space. The proposed model enables a conceptual representation of Arabic documents space, which in turn permits the semantic classification of them and thus obtaining the semantic search benefits. The system's experimental results showed an enhancement of the F-Measure value to be $81.62 \%$ using the semantic conceptual indexing instead of $63.04 \%$ using the standard syntactic one. Still, the model's implementation suffers some limitations. Consequently, the above results will certainly be improved if those limitations are overcome. And so, we are working on solving the ambiguity problem by discriminating the meaning contextually. Moreover, we are working on refining the processing of the phrasal expansions. That will improve the results noticeably since $12 \%$ of the semantic expansions are in the form of phrases.

\section{Acknowledgment}

Special thanks to the RDI's team; Prof. Dr. Mohsen Rashwan, Mrs.Asma's Rashwan, and Eng. Ala'a Badr for their assistance to use the Swift module under x64 bit framework. The authors would also like to convey thanks to Prof. Dr. Khaled Sha'lan and Dr. Mai Ouda for their effort to provide the Arabic Named Entities of a full Arabic Wikipedia dump. The first author would would especially like to thank her sister, Eng. Eman AlZoghby, for here support in reviewing this article.

\section{References}

[1] AraTation: An Arabic Semantic Annotation Tool. Layan M. Bin Saleh and Hend S. Al-Khalifa. s.l. : The 11th International Conference on Information Integration and Web-based Applications \& Services (iiW AS2009, 2009.

[2] Semantic internet search engine with focus on Arabic language. Naima Tazit, El Houssine Bouyakhf, Souad Sabri, Abdellah Yousfi, Karim Bouzouba. s.1. : The 1st International Sysmposium on Computers and Arabic Language \& Exhibition 2007 C KACST \& SCS, iscal.org.sa, 2007.

[3] Jorge Cardoso. Semantic Web services: theory, tools, and applications. s.l. : IGI Global, Mar 30, 2007. ISBN-13: 978-1599040455.

[4] Martin Hepp, Pieter De Leenheer, and Aldo de Moor. Ontology management: semantic web, semantic web services, and business applications. New York ; [London]: Springer, 2008. ISBN: 978-0-387-698899-1.

[5] Vipul Kashyap, Christoph Bussler, and Matthew Moran. The Semantic Web: Semantics for Data and Services on the Web (Data-Centric Systems and Applications). s.l. : Springer, 15 Aug 2008. ISBN-13: 978-3540764519.

[6] Next Generation Semantic Web and Its Application. Sou myarashmi Panigrahi and Sitanath Biswas. s.1. : IJCSI International Journal of Computer Science Issues, March 2011, Vols. 8, Is sue 2 ,

[7] OVERVIEW OF APPROA CHES TO SEMANTIC WEB SEARCH. Meena Unni, K. Baskaran. s.l. : 
International Journal of Computer Science and Communication, Ju ly-Dece mber 2011, Vols. 2, No. 2, pp. 345-349.

[8] Exploring the Advances in Semantic Search. Walter Renteria-Agualimpia, Francisco J. LópezPellicer,Ped ro R. Muro-Medrano, Javier NoguerasIso, and F.Javier Zarazaga-Soria 1. s.1. : International Symposium on Distributed Computing and Artificial Intelligence, 2010.

[9] Introduction to Semantic Search Engine. Junaidah Mohamed Kassim and Mahathir Rahmany. Selangor: International Conference on Electrical Engineering and Informatics ICEEI '09, 2009.

[10] Lilac Al-Safadi, Mai Al-Badrani, and Meshael AlJunidey. s.l. : International Journal of Computer Applications, April 2011, Vol. 19 No. 4.

[11] The Application of Vector Space Model in the Information Retrieval System. Yao-hong Zhao, Xiao-feng Shi. s.l. : Software Engineering and Knowledge Engineering: Theory and Practice, 2012. Vol. Volume 162, pp. pp 43-49 .

[12] UWN: A Large Multilingual Lexical Knowledge Base . Gerard de Melo, Gerhard Weikum. s.l. : Annual Meeting of the Association of Computational Linguistics, 2012.

[13] VSCAS: Vector Space Model- Conceptual Arabic Semantic Search System. Aya M. Al-Zoghby, Ahmed Sharaf Eldin Ahmed, Taher T. Hamza. s.l. [Submitted for publication].

[14] Beyond Concepts: Ontology as Reality Representation. Smith, Barry. 2004 : IOS Press, 73--84.

[15] Karin Breitman, Marco Antonio Casanova, and Walt Truszkowski. Semantic Web: Concepts, Technologies and Applications. s.l.: Springer London Ltd, 28 October 2010. ISBN 13: 9781849966214.

[16] A Pipeline Arabic Named Entity Recognition Using a Hybrid Approach. Oudah, M. M. and Shaalan, K. . s.l. : Proceedings of the 24th International Conference on Computational Linguistics (COLING 2012)., 2012.

[17] Arabic model for semantic web 3.0. Omar Isbaitan, Huda Al-Wahidi. s.l. : International Conference on Intelligent Semantic Web-Services and Applications, 2011.

[18] Samhaa R. El-Beltagy. Technology : Semantic Search. s.l. : ARABIC LANGUAGE TECHNOLOGY CENTER (AlTEC) : The PreSWOT Analysis, Feb 2010.

[19] Ontology Based Annotation of Text Segments. Samhaa R. El-Beltagy, Maryam Hazman, and Ahmed Rafea. Seoul, Korea : SAC '07 Proceedings of the 2007 ACM symposium on Applied computing, March 11-15, 2007.

[20] Arabic Semantic Web Applications - A Survey. Aya M. Al-Zoghby, Ahmed Sharaf Eld in Ahmed, Taher T. Hamza. s.l. : Journal of Emerging Technologies in Web Intelligence, Feb 2013. Vols. Vol 5, No 1, pp. 52-69. doi:10.4304/jetwi.5.1.5269.

\section{Authors' Profiles}

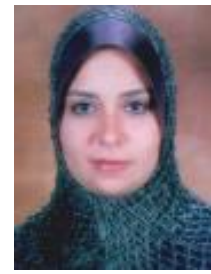

Aya M. Al-Zoghby: A PhD student at the Faculty of Computer and Information Sciences, Mansoura University. She works as a faculty staff since 2001. She holds a Master degree from the Menofeya University; and a Bachelor degree, with excellent grade and first honor, in Computer Science, Faculty of Computer and Information Sciences, Mansoura University.

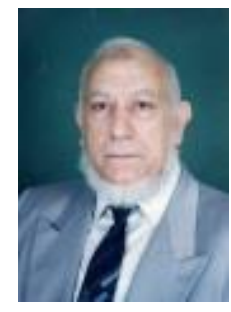

Ahmed Sharaf Eldin Ahmed: A recognized Prof. in CS and IS in Egypt. He authored more than 150 papers in international, national journals and conferences. He is the founder and coordinator of the B. Sc. Software Engineering academic program at HU. $\mathrm{He}$ is also the founder and manager of the Student Assessment Centre at HU. He was also the founder and manager of the quality assurance centre at HU. He is also one of the Egyptian members of the "Bologna Promoters" formed and funded by EU/Tempus. Its aim was to promote the Bologna process among the partner countries (Egypt is one of them). He was the coordinator of two Tempus III projects (M024A04-2004 and 31053-2003). He has a broad experience in curriculum development according to the European standards.

Taher T. Hamza: Assis. Professor of Computer Sciences, Faculty of Computers and InformationMansoura University, Vice Dean For Graduate Studies and Research.

How to cite this paper: Ay a M. Al-Zoghby, Ahmed Sharaf Eldin Ahmed, Taher T. Hamza,"Utilizing Conceptual Indexing to Enhance the Effectiveness of Vector Space Model", International Journal of Information Technology and Computer Science(IJITCS), vol.5, no.11, pp.1-12, 2013. DOI: 10.5815/ijitcs.2013.11.01 